University of Nebraska - Lincoln

DigitalCommons@University of Nebraska - Lincoln

Papers in Veterinary and Biomedical Science

Veterinary and Biomedical Sciences,

Department of

1964

Viral Infections of Domestic Animals

George A. Young

University of Nebraska - Lincoln

Follow this and additional works at: https://digitalcommons.unl.edu/vetscipapers

Part of the Veterinary Medicine Commons

Young, George A., "Viral Infections of Domestic Animals" (1964). Papers in Veterinary and Biomedical Science. 114.

https://digitalcommons.unl.edu/vetscipapers/114

This Article is brought to you for free and open access by the Veterinary and Biomedical Sciences, Department of at DigitalCommons@University of Nebraska - Lincoln. It has been accepted for inclusion in Papers in Veterinary and Biomedical Science by an authorized administrator of DigitalCommons@University of Nebraska - Lincoln. 


\title{
Viral Infections of Domestic Animals
}

\author{
George A. Young
}

Department of Veterinary Science, University of Nebraska, Lincoln, Nebraska

Contents

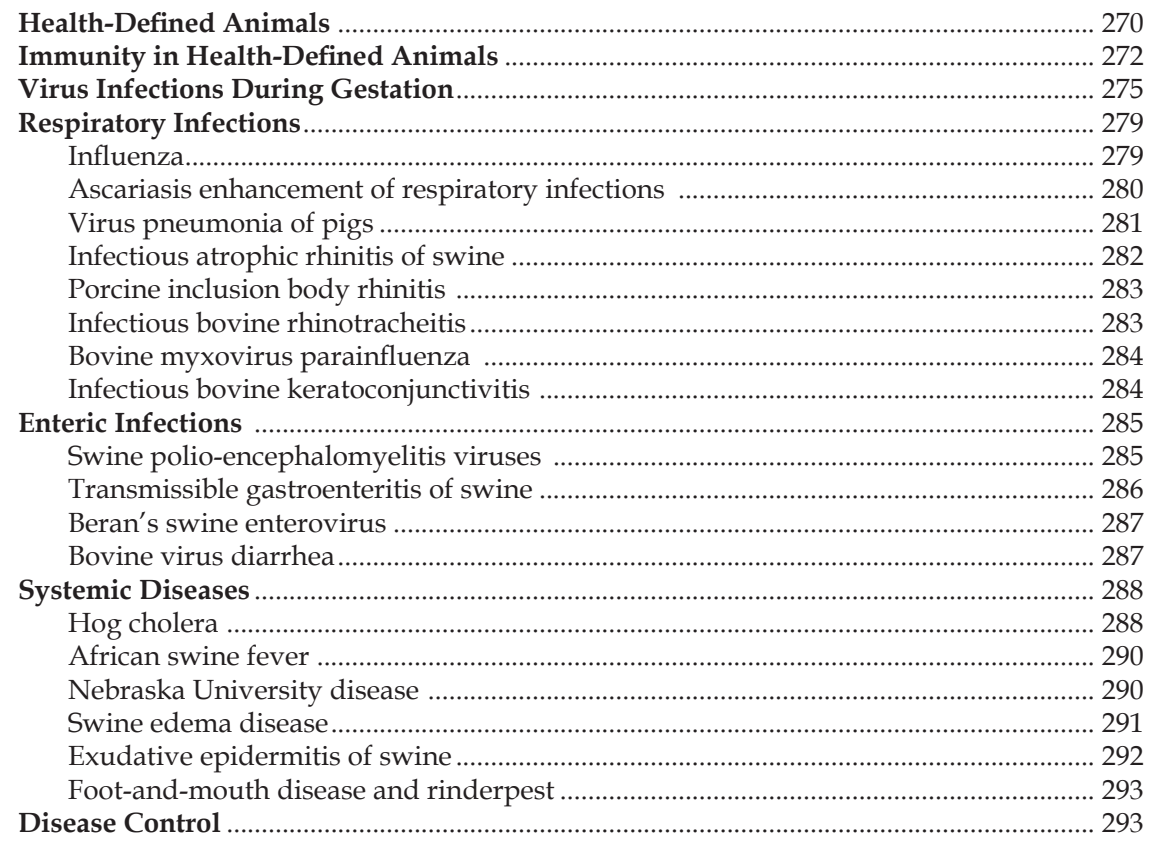

Literature citations serve as a basis for discussion of selected host-virus relationships. A complete coverage of the literature is not intended.

Abbreviations: PFCD (pathogen-free colostrum-deprived); PPLO (pleuropneumonia-like organisms); SPF (specific pathogen-free)

$\mathrm{T}$ here is a strong tendency in current research on mammalian virus diseases to concentrate on virus activity at a cellular or subcellular level. This trend is summarized adequately by Enders (1) in relation to viral replication as follows: "The large and ever-increasing volume of published experimental work on viral replication strikingly reveals the central position of this phenomenon in contemporary virological research. There are good reasons, both biological and practical, underlying this intensive effort to understand, in detail, how a virus particle, without energy transforming apparatus of its own, manages to utilize the metabolic equipment of the cell 
to produce itself. At present, the specialists in this subject conceive of replication as mediated essentially by viral nucleic acids which assume the role of the cellular nucleic acids, thereby directing the synthesis of more nucleic acid of their own kind and providing the information necessary for the manufacture of more viral protein. The enzymatic complement for these syntheses is supplied by the host cell, and the metabolic sequences are not considered to differ in essence from those involved in the manufacture of cellular nucleic acids and proteins."

Unquestionably, basic research directed toward an understanding of virus replication will play an important role in the eventual control of virus infections whether in man or his animals. Viruses in tissue culture systems may behave quite differently than in the total animal host. Essentially, there are no restraining influences so that viruses may replicate in culture at will with severe damage to or destruction of the cells they attack. A parallel seemingly exists between virus replication in a tissue culture system and replication in the total host with the experimental production of clinical or subclinical disease. The virus which causes infectious bovine rhinotracheitis of cattle behaves in this manner. However, the virus which attacks a tissue culture system with all the traits of a pathogenic entity, including cytopathogenic effects on cells, yet lacks the capacity to cause measureable disease in the fully susceptible host, does not fit the model. Beran's swine enterovirus behaves in this manner. More difficult to explain is the virus that produces disease and death in a specific host yet resists adaptation to tissue culture systems, in spite of every device the investigator may employ to encourage adaptation. This category is fulfilled by transmissible gastroenteritis virus of swine. All three viruses will be discussed later in this chapter.

Although much can be learned about viruses and virus infections in relatively simple systems, diseases in the animal and their control are still of paramount importance. Contemporary virological research, then, must maintain a proportionate balance between studies at the cellular and subcellular levels and those conducted within the animal host. Use of health-defined animals in experimental programs in recent years has greatly strengthened the position of those who would attempt to gain understanding of disease processes in the animal.

\section{Health- Defined Animals}

The terminology to be used in the chapter relating to the definition of state of health of animals includes "germ-free," "pathogen-free," "specific pathogen-free," and "conventional." "Germ-free" is defined as an animal free of all other life and one that exists in an uncontaminated environment. This is an idealistic state to which Reyniers (2) ascribes definite limitations based on our current knowledge of living things. "Pathogen-free" is defined as a state of freedom from microorganisms which would be harmful to the animal. This is a state of health that can be obtained in a practical manner for animals which may be used experimentally. "Specific pathogen-free" is less 
limiting than "pathogen-free" in that specific disease-producing microorganisms have been eliminated with safeguards to keep them continually out of the SPF population. "Conventional" is defined as a state of associated microbial life within an animal which may include harmful or disease-producing microbes as well as harmless ones.

Germ-free and pathogen-free animals have essentially the same origin. With few exceptions, the fetal animal lives within its mother in a germ-free state. Aseptic delivery of the fetus near term by hysterectomy or caesarean section into a sterile environment retains the germ-free status of these animals independently of the maternal environment. Raising germ-free animals is difficult because of the precise manner in which they must be fed and housed to keep them free of all bacteria and viruses. The pathogen-free animal is less difficult to raise as it may be gradually adapted from its germ-free state at birth to accept, in the digestive tract, saphrophytic bacteria. The SPF animal is a derivative of either germ-free or pathogen-free animals and may be obtained by natural birth. Adequate environmental control is essential to retain freedom from undesirable microbiota. Reviews relative to the germfree state and its consideration to the time of Pasteur have been made by Reyniers (2), Luckey (3), and Gordon (4). A review relative to the procurement and rearing of pathogen-free and SPF pigs has been made recently by Young (5), whereas Meyer et al. (6) have described their experiences with germ-free pigs. A bibliography by Teah (7), which encompasses germ-free research from 1 885-1963, would serve as a useful background for persons interested in this subject area.

The germ-free and pathogen-free animal eliminates some of the difficulties which have limited investigators of virus diseases of animals by providing suitable experimental hosts. Many viruses are host-specific and resist adaptation to other animals as well as to tissue culture systems or embryonated hen's eggs. The ideal experimental host would be an animal of the species naturally susceptible to the virus but which comes from herds that have had no previous experience with the virus under investigation. Such animals should preferably be free of other viruses which might be activated from latency during the course of experimentation, thereby complicating interpretation of the clinical disease. It is nearly impossible to obtain such a host from a natural environment because at birth they are exposed to all respiratory and enteric viruses and many types of bacteria common to their dam. Animals derived by hysterectomy or caesarean birth and properly raised in isolation, fulfill many of the needs for specific experimental hosts. Not only are these animals pathogen-free but many, such as the calf, lamb, and pig, are antibody-devoid because the lactoglobulin-rich colostral milk is not ingested at birth as would occur in nature since these animals are fed artificial diets. These animals are referred to as pathogen-free colostrum-deprived.

Natural disease in animals may be complex. To isolate a single entity and ascribe the intensity of disease to that one entity may be misrepresentative. Several entities, i.e., viruses, bacteria, and other parasites, may act simultaneously or in succession to produce a disease state which cannot be obtained 
with a single entity. A review of the earlier literature relative to this type of situation in animal diseases has been presented by Olson (8). The study of such complex situations using "conventional" animals is essentially fruitless because of the multiplicity of unknowns in the microbial background of such a host. By contrast, the PFCD animal is satisfactory because the corresponding entities may be added singly or in unison to approach the complex situations encountered in a natural infection. Yager (9) has discussed the usefulness of these animals in experimentation.

Pathogen-free colostrum-deprived calves (10), lambs (11), and pigs (5) are being used as experimental hosts to aid in the definition of virus diseases of these species. Pigs have been used most liberally in this respect because of their availability and relatively lower costs. The sow generally has 8 to 12 pigs per litter, whereas the ewe and cow generally present single fetuses. Since the pig has been used most liberally both in this laboratory and others, the interpretation of virus infections in animals through research with PFCD pigs will receive emphasis in this chapter.

\section{Immunity in Health-Defined Animals}

There are several basic differences in immunity in our domestic animals in contrast to most other animals and man, which must be considered in a discussion of virus diseases and their control. Whereas there is a degree of placental transfer of globulins from mother to fetus in man, rodents, and carnivores, our domestic animals do not share this trait. The placenta of the mare, the cow, the ewe, and the sow acts as a barrier to the transport of globulins. For example, Kulangara \& Schechtman (12) report that neither albumin nor globulins were present in the blood of the newborn calf. Albumin and some globulin were present in the blood of newborn kittens. Both albumin and globulins were present at birth in guinea pigs. Concepts differ as to why these species variances occur.

The concept advanced by Brambell toward the prenatal transference of antibodies as interpreted by Payne \& Marsh (13) may be summarized as follows: The blood level of antibodies at the time of birth is directly correlated with the development, persistence, and time of withdrawal of the yolk sac into the umbilical cord. In the newborn animals which have a relatively high level of blood antibody, the yolk sac is exposed to the uterine lumen during most of gestation. Animals which have only a slight globulin level at birth (calf, horse, pig) withdraw the yolk sac into the umbilical cord early in gestation and there is little prenatal absorption. This explanation is in contrast to the common opinion expressed by Mason \& Dalling (14) that the number of layers of the maternal and fetal placentae determines the transfer of antibodies. By this interpretation, transfer of antibody decreases as the placental layers increase.

The newborn foal, calf, lamb, or piglet are born without adequate globulins to protect them from infectious entities present in their natural environments. Protection is naturally acquired through ingestion of the lactoglobu- 
lins in the colostral milk of the dams. The globulins thus acquired represent only those diseases and antigenic stimuli experienced by the dams previously, and to which the dams responded with antibody production.

Some recent comprehensive studies on globulin absorption by Payne \& Marsh $(13,15)$, utilizing fluorescein-labeled gamma globulins and PFCD pigs have disclosed some interesting relationships. Intestinal cells apparently follow the all-or-none law of physiology. The cells seem to engulf all the globulins they can contain before allowing any to pass through the base of the cell into the lymphatics. The intestinal cells, on first contact with globulin, will accept heterologous globulin from other species although homologous globulin does appear to be preferentially absorbed. Absorption takes place for a limited time only after contact with globulins or other proteins. Exposure to milk protein or other protein before exposure to globulin conditions the cells to be refractory to globulin absorption.

When fluorescein-labeled gamma globulin was injected directly into the ligated small intestine of the newborn PFCD pig $24 \mathrm{hr}$ after feeding, there was no absorption anterior to the ligature. There was always active absorption in the posterior segment where the gut had not been exposed to protein. When normal cow colostrum was fed to a pig in which the small intestine had been ligated, the blood level of gamma globulin rose to approximately the normal level of the nursing pig, yet the starved segment retained its ability to absorb. In other experiments designed to study the influence of a high blood level of gamma globulin on absorption, relatively large amounts of fractionated colostral gamma globulin were injected into the peritoneal cavity. The high blood level of gamma globulin absorbed from the peritoneal cavity failed to alter the absorptive ability of intestinal cells in previously starved pigs. It thus appears that the epithelial cells of the small intestine must be exposed to a soluble protein from the direction of the microvilli and not from the direction of the capillary bed, to lose their capacity to absorb globulin.

A previous concept of active and passive immunity was that the newborn calf, lamb, or pig is born without antibody. In more recent investigations, measurements of serum proteins by electrophoresis indicate that small amounts of globulin or globulin-like substances are present in the serum of the newborn animal before it suckles its dam. The significance of this has been studied by several different groups with varying opinions as to its significance. Segre \& Kaeberle $(16,17)$ used the PFCD pig as an experimental host in their studies of the mechanics of antibody formation. Diphtheria and tetanus toxoids were used as specific antigens. These researchers believe that the small amounts of globulin-like material result from a degree of placental transfer of maternal antibody. These globulin-like materials form a base for antibody production following stimulation of the newborn pig with antigenic material related to the transferred antibody. The ability of the PFCD pig to produce some antibody to tetanus toxoid but not to diphtheria toxoid was attributed to contact of the dam during gestation to tetanus organisms with production of slight amounts of tetanus antibodies. These theoretically 
passed the placental barrier to become the globulin-like base from which active tetanus antibody was produced after birth following injection of tetanus toxoid. Segre \& Kaeberle did not consider the possibility that tetanus toxins might pass the placental barrier and initiate active immunity in the fetuses. This concept is as plausible as the one they present.

Payne \& Marsh $(13,15)$ also recognized the presence of small amounts of globulin or globulin-like substances but hesitated to identify them as true globulin. Sterzl et al. (18) have presented data which suggested to them that the gamma globulin in the pig at birth is not antibody. This concept would be supported by the experiences of Young and Underdahl who have used several thousand PFCD pigs in virus transmission experiments beginning in 1949. The PFCD animal has been consistently susceptible to all viruses studied.

New findings, which have similar significance to the finding of globulin-like substances in the serum of the newborn animal, point toward stimulation of active immunity of the fetus late in gestation by viral infections. In these instances, the virus must be mild enough to elicit infection without serious damage to the fetus. Weiss (19) demonstrated active immunity in newborn lambs that had originated from ewes experimentally infected with Rift Valley Fever virus late in gestation. Few animals were used but the evidence was convincing enough to stimulate and warrant further study in this field. Aiken \& Blore (20) were similarly able to demonstrate production of active immunity to hog cholera in the swine fetus by the introduction of modified live virus. Since these viruses are apparently incapable of reaching the fetus late in gestation by natural means, these researchers introduced the virus directly into the fetus through the uterine wall of the sow after surgical invasion of the abdominal cavity. Fetuses so treated were immune to challenge with virulent hog cholera virus after birth by hysterectomy. Nursing was not permitted so that immunity was active rather than passive in nature. A similar relationship, demonstrating that the fetus is competent to develop antibodies, has been reported by Fennestad \& BorgPetersen (21) for Brucella-infected calves and bovine fetuses injected with Leptospira. The apparent inability of the newborn animal to develop active immunity thus does not appear to be due to incompetence but rather to interference by specific lactoglobulins absorbed from the dam's milk. This phenomenon is discussed below.

Although the globulins absorbed from colostrum serve to protect the newborn animal by passive immunity from those diseases which were previously experienced by the mother, some practical difficulties arise from this type of immunity in livestock production. The antibodies absorbed from colostrum protect cells from invasion by viruses introduced purposely as vaccines to elicit active immunity. When the newborn animal has nursed before injection with virus, cell receptor sites may be blocked, virus produced may be neutralized by passive antibodies, and active immunity is not stimulated because of insufficient viral antigen. This phenomenon is generally referred to as antibody block. Hoerlein (22) demonstrated some of the basic princi- 
ples, using killed antigens. Examples involving viruses are cited by Aiken (23), Coggins (24), Dunne (25), Weide and co-workers $(26,27)$ for hog cholera in pigs; Bekkum \& Frenkel (28) for foot-and-mouth disease in pigs; Livingston \& Hardy (29) for bluetongue in lambs; Weiss (19) for Rift Valley fever in lambs; and Brown (30) for rinderpest in calves.

In most instances, antibodies act to abort specific diseases or at least to modify them. Control of transmissible gastroenteritis, however, depends on continual nursing of the immune dam having some level of antibody in the milk, according to Haelterman (31). The surface of the intestinal cells is coated with antibody and the enteritis virus is unable to attack cells in sufficient numbers to manifest apparent disease. Placement of the pigs which have received colostral antibodies to gastroenteritis on a nonimmune sow to suckle, results in loss of resistance and frank fatal infection even though these pigs have circulating antibodies which are ingested earlier from an immune dam.

\section{Virus Infections During Gestation}

Use of the total animal is essential in investigations of virus infections of the mother during gestation and the evaluation of their influence on the developing fetus. Incrimination of the infectious agent in naturally occurring disease has been based largely on circumstantial evidence. Reviews of these relationships have been presented by Blattner \& Heys (32) and Rhodes (33, 34 ) in general, and by Roberts (35) as pertains to the veterinary literature.

The viruses which have been associated with disturbances of fetuses in domestic animals may be placed in two categories. They are: (a) viruses identified with resorbed, malformed, or aborted fetuses in natural or manmade infections, and (b) viruses used experimentally to reproduce those situations observed in nature. Only those instances in which either a known viral entity was specifically introduced or a viral entity was isolated from fetal tissues are included in the first category. Representative viruses which have been reported to have an association with the development of embryonic or fetal disturbances in swine, sheep, and cattle are listed in Table I. Viruses associated with similar disturbances for horses are not listed.

The current popular interpretation of the involvement of viruses in fetuses is based on the early observations of Gregg (55) in Australia. Rubella virus which infected women during the first trimester of pregnancy, was blamed for adverse influences on the developing fetus. The most severe damage was done to those fetuses attacked early, with more moderate damage to those near the third month of gestation. Teratologic damage primarily involved the eyes and ears, and, to a lesser extent, the heart and brain. Similar patterns have been suspected for mumps virus infection but the evidence is vague.

A response in animals similar to the one observed as the result of rubella infections in pregnant women involved a rabbit-attenuated hog cholera virus (36). This modified virus was utilized in a vaccine intended for the immuni- 
zation of swine against the naturally occurring disease. Vaccination of pregnant sows during the first 30 days of gestation resulted, at term, in a high incidence of stillborn pigs and live pigs with ascites. Since the gestation period of the sow is 114 days, the 30-day period is comparable to the first trimester of pregnancy in women. This attenuated cholera virus did not adversely affect fetuses when used in sows several days before conception or after the first 30 days of gestation.

Experiences similar to those described with modified cholera virus vaccines have been encountered with other viruses intended as aids in the control of animal diseases. Shultz \& DeLay (43) have described losses among newborn lambs which were associated with the vaccination of pregnant ewes with attenuated strains of bluetongue virus. The pattern was similar to that described for rubella and hog cholera with the maximal effect on the ovine fetuses in those ewes vaccinated between 35 to 45 days. The normal gestation period of the ewe is 150 days, hence the fetus is most vulnerable within the first trimester of pregnancy.

Experiments designed to elucidate the effects of viral infections of the mother during gestation on the developing fetuses must be both carefully

Table I. Animal Viruses Associated with Damaged Fetuses in Pregnant Dams

Species and Virus Literature Cited*

Bovine

Epizootic bovine abortion

Infectious bovine rhinotracheitis

Kennedy et al. (52); Storz et al. (53)

McKercher \& Wada (54)

Ovine

Bluetongue
Rift Valley fever
Wesselsbron
Ovine abortion
Middelburg
Friend
Ornithosis

Shultz \& DeLay (43)

Findlay (44); Weiss (19)

Weiss et al. (45); Belonje (46);

le Roux (47)

Parker \& Younger (48)

Kokernot et al. (49)

Mirand \& Grace (50)

Pierce et al. (51)

Swine

Modified hog cholera

Japanese B encephalomyelitis

Pseudorabies

Young $(36,37)$; Young et al. (38);

Stair et al. (39)

Burns (40); Shimizu et al. (41)

Gordon \& Luke (42); Stair et al. (39)

\footnotetext{
* Not listed unless clear identity of virus associated either through isolation of virus or injection of specific viral entity. References not intended to be all inclusive but representative.
} 
planned and interpreted since interactions between several dynamic biological systems are involved. The mammalian embryo transcends from the union of sperm and ovum into a complex multicellular organism within a very short time. The embryo in swine, for example, is virtually completed within 30 days or approximately the first trimester (56). The elaboration of established systems and growth of the fetus occur during the last two-thirds of the gestation period.

The virus-embryo host system must be considered independently of the virus-maternal host system from several aspects. Whereas the maternal host has a complex array of defenses against lethal infection, the embryo host has essentially none. The placenta acts as a barrier to the passage of globulins so that immunity developed by the dam against the invading virus is unable to control virus infection in the embryo. Once the virus reaches the embryo, it may multiply unchecked by neutralizing antibodies of the dam.

Experimental evaluation of embryonic viral infections of domestic animals must essentially be done within the given species. Studies in mice, rats, guinea pigs, or carnivorous animals in general are not comparable. In these species, globulins do pass the placenta so that viral infections of the fetus may be influenced by neutralizing antibody of the mother. The logical means of transport of the virus to the embryo is by the blood stream of the dam during viremia. Since viremia would result from progressive multiplication of virus in the mother, the maternal antibody-producing mechanisms would have been stimulated prior to transport of the virus to the fetus. The fetal infection could thus be influenced by antibody of the dam, the production of antibody being initiated earlier by virus attack on the maternal host system. A lead time of several hours might be significant in many virus-host systems.

The choice of virus for an experimental study of maternal-fetal infections depends on the type of situation which is to be reproduced. The rubella-modified, cholera virus-modified bluetongue virus type of situation requires the choice of a mildly pathogenic virus. The infectious agent must be capable of attack on fetal cells but be sublethal in its total effect. The virus inflicts teratologic damage with abnormalities of the eyes and ears (rubella virus), generalized edema and ascites (modified cholera virus), or hydrocephalus (modified bluetongue virus).

In most instances in domestic animals, the fetus is killed by the virus. The time of death relative to the end of the normal gestation period influences the clinical manifestations of the disease. An attack on the dam during the embryonic stage of the developing young may result in the death of the embryo or embryos with complete or nearly complete aseptic (bacterial) absorption. Initiation of pregnancy with well-implanted corpora lutea prevents the dam from return to estrus even though the embryos have been destroyed. The placenta may be retained and also resorbed.

Attack of embryos or fetuses after they have reached some size presents a different picture. If all embryos are destroyed, abortion may occur with shedding of fetuses and placental tissues. Fetuses in multiparous animals such as 
the sow may die at different intervals in the gestation period. One living fetus is adequate to maintain pregnancy. Expulsion of the placenta with fetuses in all stages of resorption at term may result. Such a situation is presented pictorially by Young et al. (38) in an experimental litter which was damaged by modified cholera virus.

The SPF sow has been a useful experimental animal for the study of virus-maternal-fetal relationships. The pathogen-free background limits the types of infectious entities that might complicate the interpretation of results. The sow is multiparous and generally has 8 to 12 fetuses, each of which is in its own placental sac. These fetuses are distributed uniformly along the entirety of a two-horned uterus. Stair (57) has utilized a bifid hysterectomy to take advantage of this anatomic structure in the study of virus infection of the fetus. The dam may be infected early in gestation. Following her initial recovery from the virus infection, one horn of the uterus is removed surgically for study of the effects of the virus on the embryo. The other horn is left intact. The embryos in this horn may be left for later removal and study of more advanced stages of embryonic infection, or the fetuses may be left to mature. They may be delivered by a total hysterectomy near the end of gestation.

The identification of virus locale has not been possible by many techniques used to associate virus with damaged or dead embryos or fetuses. Inoculation of experimental animals or tissue culture systems with suspension of triturated tissues from embryos may indicate the presence of virus but does not identify the site of the virus in the embryo. Stair et al. (39) have utilized fluorescent-tagged specific antiglobulins to demonstrate both hog cholera and pseudorabies virus in embryonic or fetal tissues.

Patterns of attack differ so that each virus-host system must be considered separately. Modified hog cholera viruses fit the conventionally considered pattern based on the evaluation of rubella virus infections in pregnant women. Attack of the embryo during the first trimester of gestation results in teratologic or lethal damage to the embryo. Virus is demonstrable in fetal reticuloendothelial tissues by immunofluorescence techniques. Maternal infection which occurs later in gestation generally results in failure of the virus to reach the embryo. Immunofluorescence techniques fail to disclose the cholera antigen deposited in fetuses. By contrast, pseudorabies virus appears to be incapable of establishing itself in the young swine embryo through the first 30 days, but may reach the fetuses on maternal infection during the last trimester of gestation. The effect on each fetus is all-or-none. Those embryos attacked are killed and give positive immunofluorescence tests for pseudorabies, whereas those which are not killed are normal at birth by hysterectomy and susceptible to infection on experimental challenge in isolation as PFCD pigs. When all fetuses are killed, the litter is aborted (39). These relationships are not unlike those encountered in women (33). Smallpox and chickenpox viruses attacking the mother early in pregnancy behave similarly to pseudorabies virus in that they do not cause 
birth defects in the baby. Attacks late in pregnancy may result in the passage of virus across the placenta to invade the tissues of the fetus. The newborn infant may have the same clinical disease as the mother. Rubella virus behaves similarly to modified hog cholera in that early infection may damage the embryo, whereas infection of the mother late in pregnancy rarely affects the baby. The newborn infant is born healthy in such a case. Coxsackie and ECHO viruses may cause a feverish illness with a rash which closely resembles that produced by rubella virus. There has been no evidence of birth defects among infants from thousands of mothers infected with these viruses in the early months of pregnancy. Similarly, vaccination with vaccinia or polio viruses has failed to cause abortions or birth defects. Quite likely, the enteroviruses of domestic animals fit this type of situation. No definite conclusions can be drawn because experimental evidence is lacking.

\section{Respiratory Infections}

Influenza - A discussion of respiratory diseases in animals should include consideration of swine influenza. The primary entity of this disease is a filterable virus which causes only moderate disease as a single entity in PFCD pigs or in susceptible conventional pigs. Shope (58) referred to this transient infection in conventional pigs as "filtrates disease." Swine influenza as a clinical disease was defined by Lewis \& Shope (59) as a concerted disease with the intensification of the primary viral disease by a secondary infection with the bacterium, Hemophilus influenzae suis. As an explanation for the fact that swine influenza persisted from year to year on midwestern farms, Shope (60-63) presented circumstantial evidence which involved the swine lungworm as an intermediate host. Lungworm eggs originating from swine that were simultaneously infected with swine influenza virus and parasites of Metastrongylus spp. were voided in the stools of sick pigs. These virus-contaminated lungworm eggs were ingested by earthworms, hatched, and encysted in larval stages in the musculature of the earthworm. The larvae made their way into the lungs of susceptible pigs following ingestion by the pig of earthworms which had been infected with the lungworm larvae. Lungworms reached adult stage without the development of swine influenza although the virus was considered to be present in a "masked" stage. Overt influenza was precipitated by stress resulting from experimental injection of Ascaris suum extracts.

There has been general reluctance to accept Shope's explanation of an intermediate parasite host as a means of perpetuating swine influenza. This reluctance has not been on an editorial level but rather on a conversational level. It has stemmed from inability to identify the virus in any manner from the time it leaves the swine host until it again manifests itself as a disease entity in the animal. Attempts by Shope to demonstrate the virus in Metastrongylus spp. eggs or larvae failed. 
Approximately 20 years after Shope's explanation was presented, two separate groups of researchers published confirmatory results. Sen et al. (64) were the first to confirm Shope's findings by utilizing PFCD pigs in a well-defined and controlled isolated environment. Kammer \& Hanson (65) obtained similar results. Neither of these research groups was able to identify the swine influenza virus in the intermediate stages. Peterson et al. (66) have demonstrated, however, that swine lungworms contain receptorlike substances capable of absorbing influenza virus, a result consistent with Shope's hypothesis. Unquestionably, the virus is transported in some manner through a Metastrongylus-egg-earthworm-Metastrongylus larvae cycle to remain potentially infective for the susceptible pig. Perhaps "masking" in actuality is the presence of virus in amounts less than those required to produce experimental infection, as suggested by Beard (67) for papilloma virus. Since the presence of Metastrongylus spp. in the lungs of pigs has been shown by Underdahl \& Kelley (68) to enhance influenza infection, less virus may be needed to initiate influenza. It is a challenge to researchers to establish the mechanisms by which these things are accomplished.

Ascariasis enhancement of respiratory infections - The significance of the extract of $A$. suum used by Shope in his early work may be related to the recent findings of Underdahl (69), Underdahl \& Kelley (68), and Nayak et al. (69a). The life cycle of this parasite has been partially understood for many years. Embryonated eggs are ingested from the soil by pigs and hatch in the stomach and intestines. The larvae pass through the intestinal wall, through the liver, and through the lungs. Many of the larvae are eventually coughed up and swallowed, to reach the intestinal tract for the second time. Some of the parasites grow into adults with the females laying large numbers of eggs. These eggs may persist in the soil for years, to be ingested by other pigs and thereby perpetuate ascariasis.

The passage of a few thousand ascaris larvae through the liver and lungs of pigs causes only moderate stress. It takes large numbers, possibly larger than generally occurs in nature, to cause marked clinical illness among experimentally infected animals. Once the larvae pass through the lung, the pigs soon return to an apparent state of normalcy.

Partial concern for the effects of migrating A. suum larvae is related to the enhancement of respiratory virus infections. Swine influenza is greatly intensified when the larvae pass through the virus-infected lung, and severe clinical illness is manifested by doses of virus and parasite which, as single entities, would not cause noticeable illness (69). In some manner, the migrating parasite lowers local host resistance to permit virus multiplication. The effect, more logically, would appear to be related to the secretion of substances which enhance virus multiplication rather than due to simple mechanical damage. Considerable hemorrhage is associated with the passage of larvae through the lungs. The migrating larvae do elicit an increase in amino acid amidase activity, an activity also associated with the virus infection (70). Other enzyme systems may be similarly imbalanced. 
The natural opportunity for associated migrating larvae and swine influenza virus to cause illness is limited to an approximate 10 per cent incidence of influenza (71) in swine populations of the midwestern United States. The A. suum parasite is more widely disseminated and is estimated by Kelley et al. (72) to contaminate over 85 per cent of premises on which American swine are raised. A less likely virus-parasite combination involves influenza and lungworms since this parasite is present on only about 20 per cent of midwestern farms (73).

Virus pneumonia of pigs - A more opportune natural involvement of A. suum larvae in swine respiratory disease is presented with virus pneumonia of pigs. It has a wide distribution among the swine populations of the world (74) and has been shown by Underdahl \& Kelley (68) to be enhanced by migrating $A$. suum larvae. Since the pneumonia virus is present in approximately 40 per cent of midwestern United States swine (75) and tends to persist indefinitely in the lungs of the infected animals, the probability of pigs having both pneumonia virus and migrating $A$. suum larvae simultaneously is not remote. Virus pneumonia is perpetuated on passage of the virus from mother to offspring by carriers. The agent has been demonstrated by Betts (76) to persist for at least 66 weeks in the pig and to retain the capacity to infect other pigs.

Virus pneumonia of pigs may or may not be the proper terminology for the chronic respiratory disease of swine which is clinically characterized by persistent coughing, and histopathologically by perivascular and peribronchiolar cuffing with large and small round cells. This was the name given by Betts (76) in an early and excellent description of the disease. Lamont (77) had presented an earlier review encompassing respiratory diseases of swine in general but failed to categorize pneumonia as a distinct entity. A review by Young (74) supplements earlier reports.

Virus pneumonia is induced by the introduction of filtrates of infected lung intranasally or intratracheally into susceptible swine. Relatively coarse filters must be used to prevent passage of pleuropneumonia-like organisms. Bakos \& Dinter (78) report the isolation of a swine enzootic pneumonia or virus pneumonia agent by yolk sac inoculation of lung filtrates from infected swine. After inoculation their agent may be cultivated on PPLO agar. Betts \& Whittlestone (79) also were able to cultivate pleomorphic organisms about $0.4 \mu$ in diameter in pig-lung-monolayer tissue culture and culture material was capable of producing lesions typical of virus pneumonia in PFCD pigs. A similar agent has been described by Goodwin \& Whittlestone (80). These experiences are at variance with those obtained with the virus isolated and studied by Urman et al. (81), in that the NB-12 strain used has resisted cultivation in tissue culture and embryonated eggs. Pleuropneumonia-like organisms isolated from pneumonic lungs of market swine at slaughter in Nebraska by Plonait (82), failed to become established in the lungs of experimentally inoculated PFCD pigs. To further confuse the etiologic interpretation of virus pneumonia, Goodwin \& Whittlestone (83) have recently de- 
scribed a respiratory disease of pigs, designated Type XI, which differs from either enzootic or virus pneumonia yet is similar in many respects. Thus, the probability exists that there are several infectious entities which produce similar respiratory diseases in swine.

Comparison of diseases which occur in different countries is generally accomplished most satisfactorily by tests for similarities in serum neutralizing antibodies produced in the natural host. The difficulty with virus pneumonia is that measurable neutralization by serum antibodies is not elicited in infected swine according to Bornfors \& Lannek (84) even though recovered swine were resistant to reinfection. Several other research groups have had similar experiences. The indirect approach of Bakos \& Dinter (78), utilizing serum from hyperimmunized rabbits for specific neutralization, immunofluorescence, and agar-gel precipitation tests might be useful for comparisons. Direct immunofluorescence tests attempted in this laboratory with globulins prepared from serum of virus pneumonia-infected pigs have not been successful. Antibody production, which is essential to provide a specific globulin to which fluorescein may be attached for the immunofluorescence has not been satisfactory even though pneumonia infections were intensified by ascariasis and administration of cortisone (85).

Broad spectrum antibiotics will prevent the establishment of virus pneumonia in pigs but will not cure the disease once it is established [Bornfors \& Lannek (84); Goret et al. (86); Hupka \& Hutten (87)]. Treatment is not practical, however, as newborn pigs must be medicated individually and remain susceptible when the drugs are withdrawn. In an infected herd, therapeutic levels of antibiotics would need to be administered continuously.

Infectious atrophic rhinitis of swine - Another disease of swine which is considered very important to the economy of pork production is infectious atrophic rhinitis which has much in common with virus pneumonia. Both affect the respiratory tract although the former involves primarily the upper portion and pneumonia the apical and cardiac lobes of the lungs. These diseases are acquired by contact with infected swine or the inhalation of air contaminated by them. Both diseases are perpetuated in herds by carrier animals which apparently remain carriers over sufficiently long periods to pass the diseases from one generation to the next. There is not complete academic accord on the etiology of either rhinitis or pneumonia. The death of an animal is rarely attributed to either disease. Both diseases effect the economy of production through retardation of rate of growth and inefficient utilization of feed.

An extensive review of the early literature relative to atrophic rhinitis made by Switzer (88) in 1955 indicates the confused concept of the etiology of this disease. Many different bacteria, including PPLO, trichomonad parasites, and several viruses have been suggested as its cause. Switzer (89) suggested that several agents might be responsible for the clinical entity identified by turbinate atrophy as rhinitis. Further work by Switzer and his associates (90, 
91), using tissue culture methods enabled them to identify nine viruses and two PPLO in the nasal cavities of swine. These agents were not generally capable of producing disease in naturally farrowed SPF pigs. The viruses were entities other than Coxsackie, influenza, pseudorabies, or virus pneumonia (90). One bacterial entity, Bordetella bronchiseptica, which is believed by Switzer (92) to be an important etiological agent in atrophic rhinitis possibly is eliminated and controlled by sulfonamide therapy.

Neither rhinitis nor virus pneumonia appear to respond to therapy with known drugs and cannot currently be prevented by vaccines because none exist against these diseases. The use of sulfonamides as reported by Switzer (92) to control or eliminate Bordetella bronchiseptica infection appears to be misleading because the experiences of American veterinarians in swine practice with rhinitis during the 1950's contradict this. A recent development in the American feed industry wherein sulfonamides are included as feed additives for swine should yield practical information on this point. A marked reduction in the disease should be effected among swine in the United States cornbelt.

It is questionable that the basic etiology of rhinitis has been determined. In the natural disease, young susceptible pigs are attacked, often with severe turbinate atrophy. Pathogen-free colostrum deprived pigs placed in contact with animals severely affected with natural rhinitis, develop marked atrophy. By providing a continuous series of contact PFCD pigs, the severe form of the infection may be progressively passed. This suggests the association of a viral entity(ies) with rhinitis which has not been consistently demonstrable by the methods used previously in its study.

Porcine inclusion body rhinitis - The inclusion body rhinitis described by Done (93) does not appear to be the same disease or related to atrophic rhinitis. This disease has also been reported in Canada by Mitchell \& Corner (94), in central Europe by Cohrs (95), and in the United States (Iowa) by Duncan et al. (96). The clinical disease is more acute than atrophic rhinitis but does not generally produce turbinate atrophy. Excessive exudation from the nostrils is typical.

Infectious bovine rhinotracheitis - The isolation and characterization of new viruses associated with illness among cattle has previously been hampered by uncertainty of the immunological state or susceptibility of the experimental host. Tissue culture methods have been helpful in overcoming this limitation. Viruses isolated in tissue culture can be subjected to serumneutralization tests to evaluate possible previous encounter of individual or groups of calves to that specific virus or closely related viruses. Studies for pathogenicity of the tissue culture virus in experimental calves with known immune status have much more significance.

An example of the usefulness of tissue culture systems in evaluating bovine virus diseases is evident from results obtained with the agent which causes infectious bovine rhinotracheitis. This is an acute upper respiratory 
infection in cattle which was first isolated by Madin et al. (97). The disease was shown by McKercher et al. (98) to be caused by a single virus entity among dairy and feeder cattle in California as well as feeder cattle in Colorado. Brown \& Cabasso (99) succeeded in the experimental transmission of the disease. Infectious bovine rhinotracheitis virus has been shown by Gillespie et al. (100) to be related to or to be the same virus as that which causes infectious pustular vulvovaginitis in cattle. Cheatham \& Crandell (101) demonstrated intranuclear inclusions associated with virus-infected tissue culture cells. This was later demonstrated in experimentally infected animals by Crandell et al. (102).

Cultivation of the bovine rhinotracheitis virus in tissue culture [See Gillespie et al. (103) ; Cabasso et al. (104) ; Schwartz et al. $(105,106)]$ and modification of the virulence of the virus has made vaccines practical for moderating the natural disease. These vaccines are effectively and widely used, especially in large feed lots where thousands of cattle are being fattened for market. An intangible but definite impression exists among veterinarians that there are fewer total respiratory problems among rhinotracheitis-vaccinated cattle even though the virus had not previously been identified as a clinical entity within the population. The vaccines must be properly used as indicated by McKercher et al. (54), as vaccination has been associated with abortion among cattle.

Bovine myxovirus parainfluenza 3 - Considerable progress has been made in recent years on the viral etiology of "shipping fever" in cattle. Reisinger et al. (107) succeeded in isolating a virus from calves ill with a respiratory disease which has now been classed as a bovine myxovirus parainfluenza 3. The strain designation was made as SF-4. Several research groups have presented evidence based on serological studies that the virus is widely distributed in cattle. Hoerlein et al. (108) report antibodies in feeder calves in Illinois, whereas Abinanti et al. (109) reported later a widespread incidence of parainfluenza antibodies among cattle. Kramer et al. (110) found evidence of a wide distribution of the virus in both beef and dairy cattle in $\mathrm{Ne}$ braska. Dawson (111), on comparison of his T1 strain of parainfluenza virus with the SF-4 American strain and the Umea 33 Swedish strain, found a general relationship between all three strains of the organism. In contrast to this work, Hamdy et al. (112) report the production of a "shipping fever-like" syndrome with combinations of viruses and Pasteurella spp. The viruses used were parainfluenza 3 , bovine rhinotracheitis, and psittacosis lymphogranuloma venereum.

Infectious bovine keratoconjunctivitis - Infectious bovine keratoconjunctivitis ("Pinkeye") is a disease of cattle which has a history similar to that of "Shipping Fever." Satisfactory evidence for any bacterial agent as the primary cause of Pinkeye is lacking. Sykes et al. (113), however, have isolated a virus from cattle clinically ill with what they interpreted as infectious bovine keratoconjunctivitis. The failure of 7 of 12 heifers to become clinically ill even 
though by serum neutralization tests they should have been susceptible, attests to the mild effects of this agent. This virus was shown to be unrelated to bovine rhinotracheitis, bovine virus diarrhea, parainfluenza 3, Nebraska mucosal disease agent (114), bovine respiratory virus, and pneumonoenteritis virus. Experiments by Sweat (10) in PFCD calves kept in strict isolation indicate a definite primary capacity for invasion by this agent. The experimental disease is characterized mainly by dramatic and sudden loss of weight by calves but without corneal opacity typical of the infectious bovine keratoconjunctivitis. Thus, it would appear that what is clinically referred to as Pinkeye in cattle has an etiological background currently as vague as Shipping Fever. Obviously, much critical research is needed. The usefulness of PFCD calves (10) in these investigations is obvious but their availability and cost of approximately $\$ 250$ per animal, plus the need for maximal isolation, are limiting factors.

\section{Enteric Infections}

Tissue culture systems have been used extensively in the study of viruses isolated from the intestinal tract of domestic animals. Considerable emphasis has been placed on enteric viruses of swine utilizing swine kidney cell cultures for the isolation (115) of viruses, and determination of their growth characteristics (116). Tissue culture systems have also served as the source of virus for purification of swine enteroviruses and swinepox viruses, using an ion exchange cellulose column (117).

Swine polio-encephalomyelitis viruses - Comparison of the immunological relationships of polio-encephalomyelitis viruses has been made possible through the use of tissue culture systems. For example, Teschen disease, reviewed by Huck et al. (115), is an enzootic encephalitic disease of swine in central Europe. The occurrence of similar diseases of swine in other geographic areas prompted comparative studies between virus strains. Evidence that several of these diseases are closely related or identical has been presented by several groups of researchers. Chaproniere et al. (119) grew Talfan virus in tissue culture and used infected fluids as inoculum to reproduce the disease in pigs. Cross neutralization of Teschen and Talfan antiserums disclosed similarities between the two diseases. Darbyshire \& Dawson (120) found a similar relationship, using a complement-fixation test, and also compared two other swine polio-encephalomyelitis viruses to Teschen and Talfan viruses (T80 and T52A). Huck et al. (118), studying viruses isolated by Izawa et al. (121), demonstrated that the California isolated viruses E1 and E4 were related to Teschen and T80 groups of swine enteroviruses, respectively. The E1 virus was associated with a natural epizootic of diarrhea among pigs, whereas the E4 virus was obtained from feces of a clinically normal pig. The T80 virus was isolated by Betts (122) from the tonsils of "normal" pigs and was capable of producing polio-encephalomyelitis in PFCD pigs (123). Izawa 
et al. (121) used SPF pigs of hysterectomy origin in evaluating the pathogenicity of their viruses. The report of Huck et al. (118) presents a good review and summary of research in this field.

The hemagglutinating virus of Greig et al. (124) which produced encephalomyelitis in PFCD pigs (125) appears not to be related to the Teschenor T80 groups of viruses. The F7 enterovirus of Kelly (126) had a minor antigenic relationship to T80 virus but was distinct from Talfan, Teschen, S 180/4, T52A, and PE-1 porcine viruses. None of the viruses isolated in England or in the United States came from disease situations of the severe type associated with the virulent strains of Teschen virus of central Europe.

Transmissible gastroenteritis of swine - The most dramatic enteric infection that occurs among young swine is transmissible gastroenteritis. This is a highly contagious virus disease which inflicts heavy mortalities among very young susceptible swine. Mortalities of 90 to 100 per cent occur among pigs less than a week old. The disease was first described by Purdue researchers in 1946 and has since been reviewed by Doyle (127). All pigs 14 to 21 days old may manifest typical symptoms of vomition and diarrhea but 70 to 90 per cent generally recover within a few days. Older pigs may exhibit a slight diarrhea for a few days then recover without loss. Silent or inapparent transmissible gastroenteritis infections occur and viremia was demonstrated by Young et al. (128) in asymptomatic pigs by the inoculation of their blood into very young susceptible pigs. Evidence of previous infection by six- to eightfold shifts in specific serum neutralization antibodies can be demonstrated by a test described by Young et al. (129), using PFCD pigs less than five days old to indicate the presence of virus not neutralized in vitro.

Study of transmissible gastroenteritis has been limited for all practical purposes to the experimental disease in susceptible pigs. The agent has resisted adaptation to other species and to tissue culture systems. Lee (130) and Eto et al. (131) have reported adaptation of the virus to tissue culture. Most researchers in the United States, however, have had experiences similar to Haelterman's (31) in that enteritis virus does not grow in tissue culture systems. The cultured viruses reported by Lee and Eto are either not gastroenteritis or have characteristics quite different from those of the strains worked with in most American laboratories.

Misinterpretations of transmissible gastroenteritis infection occur in spite of an accumulation of knowledge such as outlined above. For example, a severe enzootic of the disease manifested itself with severe symptoms and heavy losses among the young pigs in a moderate sized herd. Forty additional sows were to begin farrowing within two weeks so these were isolated about one-half mile away. The farrowing quarters were evacuated, thoroughly cleaned, gassed with formaldehyde, and rested for two weeks prior to farrow of the new litters. Lack of evidence of gastroenteritis in the subsequently farrowed litters, the first interpreted as the successful avoidance of exposure of the new pigs to the virus. Actually, the dams had undergone inapparent infections even though precautions were taken to prevent their ex- 
posure. Significant rises in serum neutralization antibodies from none in preexposure serums to 1:16 to 1:32 in postinfection serums, indicated that the dams had been infected.

Transmissible gastroenteritis or like diseases among pigs have been reported from several other countries but it is difficult to determine if the diseases are truly related. Roe \& Alexander (132) reported a disease occurring in nursing pigs in Ontario which resembled gastroenteritis. These authors concluded on clinical observations that the disease was not the same. A highly infectious gastroenteritis reported by Goodwin \& Jennings $(133,134)$ among pigs in England also behaved like transmissible gastroenteritis in many respects. Serum neutralization tests made with their infectious agent (134) against specific immune serums prepared in the United States (129) suggested an immunologic relationship between the British disease and the Hormel strain. It was not possible to determine the exact relationship. The limiting factor for neutralization tests for transmissible gastroenteritis has been the need to use very young susceptible pigs, preferably PFCD pigs, to demonstrate neutralizing antibodies. Since the disease is highly transmissible, these tests must be conducted in isolation. The lack of adequate isolation facilities and available pigs has limited studies. A good serum neutralization test in tissue culture would be useful should someone succeed in adapting the gastroenteritis virus to a culture system.

Beran's swine enterovirus - The need for a health-defined total host to supplement tissue culture in the study of virus infections was emphasized in the research of Beran and co-workers $(135,136)$ with an enterovirus of swine. Beran's enterovirus was isolated in tissue culture from stools of swine in a conventional population that was undergoing an enteric disturbance. A cytopathic effect was obtained in a swine kidney cell tissue culture system with this virus. Infected culture fluids given to conventional pigs produced erratic results. Tests made by Beran et al. (136) with PFCD pigs, however, gave conclusive and startling results. Beran's enterovirus attacked the intestinal cells of these pigs and elicited neutralizing antibodies without the manifestation of any clinical symptoms of disease. Temperatures taken twice daily remained normal. There was no change in stool consistency. Beran's enterovirus of swine thus cannot be considered as a serious infectious entity, at least as far as the uncomplicated infection in pigs is concerned.

Bovine virus diarrhea - A group of cattle diseases referred to generally as the virus diarrhea-mucosal disease complex has received considerable attention from veterinary researchers in the past several years. One problem has been the vague and variable nature of the disease(s) which form this complex. The virus diarrhea syndrome has been more easily evaluated than the mucosal disease as several virus diarrhea agents have been isolated in tissue culture systems. The virus isolated by Underdahl et al. (114) from what was believed to be mucosal disease at the time more nearly fits the diarrhea format. 
Virus diarrhea is generally an acute or chronic, contagious febrile disease of cattle characterized by inflammation and erosion of the mucous membranes of the digestive tract associated with diarrhea, depression, dehydration, respiratory distress, and leucopenia. A major concern is the similarity of this infection to rinderpest and the need for a rapid and specific means for differential diagnosis. Specific neutralizing antibody can be detected for the diarrhea virus by virus-neutralization tests similar to the one described by Coggins (137).

Several research groups have succeeded in isolating in tissue culture viral agents [See Baker et al. (138) ; Lee \& Gillespie (139)] which have varying degrees of immunological relationship to each other. Whereas Carlson et al. (140) found their virus diarrhea under field conditions to cause mortalities near 10 per cent (range 0 to 50 percent), no deaths occurred among calves infected in the laboratory. The virus isolated by Noice \& Schipper (141) behaved similarly. This has been typical of transmission experiments both with diarrhea and mucosal disease, which suggests that all factors in the natural disease are not being encountered. Host susceptibility governed by previous experiences with the same or similar agents, proper sequence of preinfection factors and associated secondary bacteria, parasites or viruses, may not have been met in executing the experimental infections. Experiments conducted with PFCD calves utilizing agents isolated from viral diarrhea or mucosal disease might prove to be more fruitful than experiments that have been conducted using conventional calves.

Although several virus diarrhea viruses have been cultivated in tissue culture, field use of a vaccine has not been practiced. A multiplicity of diarrheal antigenic types would seem to be indicated plus some antigenic component(s) which would protect against invasion by mucosal disease viruses. A triple vaccine with leptospiral, diarrhea, and bovine rhinotracheitis antigens proposed by Baker et al. (142) has not been used beyond experimental trials.

\section{Systemic Diseases}

Hog cholera - Hog cholera continues to be one of the most important virus diseases in swine in the United States. It was first identified as a filterable virus by Dorset et al. (143) in 1904 on a follow-up of work described in the previous year. Historically, the popular belief of the origin of hog cholera is 1833 in Ohio. Hanson (144), however, in a critical re-evaluation, placed the first appearance of the disease in the United States at Franklin, Tennessee, around 1800-1810. Among the possible origins discussed was that the virus was imported in carrier animals from a country of poor husbandry in which it was not recognized or described. This explanation seems plausible based on the description by Fleming (145) of plagues in European swine in the late 1700 's. 
Hog cholera can possibly be eradicated from the swine population at an economic advantage to the producers. Plans for an eradication program in the United States have been formulated and their merits were discussed at length in a 1961 symposium edited by Mainwaring \& Sorensen (146).

The first means of control for the disease reported in 1908 (147), consisted of blocking the lethal effect of virulent cholera by the use of a viral antiserum simultaneously with the virulent virus. The concept was to elicit immunity following mild clinical infection. Some of the disadvantages of this system were overcome by Koprowski et al. (148) and Baker (149) by reducing the virulence of the virus for use in a vaccine. Modification was induced by rabbit passage. Vaccines utilizing modified live cholera virus have been in general commercial use since 1952, but killed vaccines have not been generally accepted (150). Viruses modified by passage in tissue culture have had limited acceptance although excellent claims are made for newer commercial vaccines $(151,152)$. The use of a bovine enterovirus in a vaccine for hog cholera proposed as a possibility by Beckenhauer et al. (153) and Atkinson et al. (154), has not been generally accepted. There is good evidence for a serological relationship between these viruses as indicated by Sheffy et al. (155), Gutenkunst \& Malmquist (156), Mengeling et al. (157), and Coggins \& Seo (158), but tissue culture vaccines employing the bovine virus diarrhea agent have failed to elicit general protection to hog cholera in vaccinated swine. Challenge of pigs vaccinated with the diarrhea agent with some strains of virulent cholera virus has demonstrated some protection. Challenges utilizing the standard virulent Ames test virus have not been satisfactory. General use of this type of vaccine is thus not probable.

One problem in the control of hog cholera which must be considered in an eradication program is the lack of a rapid and accurate diagnostic test. Past diagnoses have relied heavily on history, clinical symptoms, gross and microscopic pathology because the most definitive diagnosis which involved inoculation of both susceptible and immune pigs was both time-consuming and expensive. The criteria for such a diagnosis are described by Dunne (159). One serious limitation has been that swine clinically ill with most diseases and especially erysipelas, pseudorabies, Nebraska University disease, and edema disease manifest common symptoms. Histopathological lesions are frequently difficult to interpret. These limitations and emphasis on a cholera eradication program, has prompted increased activity in search of satisfactory diagnostic aids.

The use of tissue cultures with cytopathogenic effects of virus on cells neutralizable with specific antiserum has been the basis for detection and identification of many virus diseases. Although Gustafson \& Pomerat (160) were able to demonstrate the cytopathogenic effects of a laboratory strain of cholera virus on embryonic swine tissues, field viruses do not generally adapt to tissue culture to produce cytopathogenic effects, especially on isolation or early passages. The observation by Lee (161) of nuclear changes 
in cells of tissue culture systems infected with cholera virus, and the detection of intranuclear inclusion bodies by Urman et al. (162) in reticuloendothial cells of pigs infected with cholera, serve as aids to the diagnosis of the disease. These tests are not simple enough or precise enough to serve as single diagnostic tests. The conglutination complement absorption test of Millian \& Engelhard (163) and the hemagglutination test of Segre (164) are quite complex and are in need of further evaluation. These tests are better adapted to the evaluation of antibodies produced rather than as an indication of virus in the early acute phases of cholera infection. Evaluation of the agar diffusion precipitation test for cholera diagnosis by McClurkin (165) has indicated that false positives occur in the serum of pigs previously vaccinated with crystal violet vaccine. Pirtle (166), in similar studies using pancreatic tissues from SPF swine, concluded there was no evidence to relate precipitation and hog cholera virus. The test described by Taylor (167) of utilizing enzymes from the pancreas of infected pigs to hydrolyze starch has not proved precise enough for general use.

Two relatively new tests which employ specific fluorescein-labeled globulins to detect cholera virus show considerable promise as diagnostic tests. Immunofluorescence is commonly used to refer to this type of serological reaction. The specific antibodies for both cholera tests are prepared in SPF or PFCD pigs as reviewed by McDevitt et al. (168) and can be used to label and concentrate globulins. The immunofluorescence test used by Stair et al. (169) identifies the cholera viral and soluble antigens directly in the infected tissues of swine. Infection may be detected as early as the fifth day and at least through the fifteenth day. This test, based on impressions from lymph glands, spleen, or kidneys can be set up and read within an hour (170). A similar immunofluorescence test described by Mengeling et al. (171) detects antigen in a tissue culture system. Tissue extracts from pigs suspected to have cholera are inoculated into the culture system. The test is read 6 to 18 hours later. Both tests need further evaluation to determine which is most generally acceptable for the standard diagnostic laboratory.

African swine fever - A test related in significance to the hog cholera tests is the hemadsorption test developed by Malmquist \& Hay (172) for African swine fever. This is a disease of swine in Africa and parts of Europe which is immunologically distinct from hog cholera. Since there is no satisfactory vaccine for swine fever, this disease poses a continuous threat to swine industries in other parts of the world. The availability of a test which distinguishes swine fever from cholera would aid materially in limiting the spread of the former. The development of an immunofluorescence test would appear to be unlikely because of the limited antibody response to swine fever virus as reported by DeTray (173).

Nebraska University disease - The pathogen-free colostrum-deprived pig has been useful in identifying infectious entities which would have been detected only with difficulty or not at all by the use of conventional animals 
and techniques. A good example is Nebraska University disease first described by Underdahl et al. (174). This is a septicemic disease capable of inflicting heavy mortality among fully susceptible swine. Immunity develops among surviving swine but the virus persists in carriers. Herd stability to the disease is established through colostral immunity among the young pigs at a time when they are exposed to the virus, followed by development of active immunity. Infection may be so modified by the presence of antibody that the disease is inapparent.

Nebraska University disease was first identified within a group of adult SPF swine which were mingled with a group of conventional swine of similar size. Members of the conventional group appeared to be healthy. Fighting was severe among members of the two groups as they sought to establish a new social order. Within three days, one-third of the SPF group was seriously ill, with animals dying on the third and fourth days. Those which died first were SPF pigs most severely lacerated from fighting in the new social order. None of the conventional pigs died although they sustained lacerations as severe as those of the SPF pigs. Contact experiments, utilizing PFCD pigs, were conducted which resulted in the isolation of a specific infectious filterable and noncultivatable entity recognized as the causative agent of the $\mathrm{Ne}$ braska disease.

Six months after the introduction of the first group of SPF pigs into the herd described above, a second group was introduced. The pathogen-free and conventional animals were not placed together in lots but were permitted use of common waterers and feeders with fence contact. Fighting did not occur and no illnesses developed in individuals of either group. This could have been interpreted as disappearance of the Nebraska agent from the conventional population. Serum neutralization tests did not support this view. Tests on paired serum samples from the SPF animals taken previous to and one month after exposure to the conventional group disclosed the development of specific neutralizing antibody to the Nebraska agent. The conclusions drawn were that the agent has moderate virulence and the normal defense mechanisms can adequately handle moderate doses of the infectious agent. The dosage inflicted through lacerated skin during fighting was large enough to overwhelm the defense systems, permitting fatal infection.

Swine edema disease - An infectious agent associated with edema disease of swine, also first described by Underdahl et al. $(175,176)$, who used PFCD pigs as experimental hosts, has some similarities to Nebraska University disease. The diseases are immunologically distinct. Both cause clinical illnesses which are similar to each other and to acute swine erysipelas or hog cholera. A differential diagnosis therefore becomes of the utmost importance.

There is considerable controversy as to the cause of edema disease in swine. Literature reviews by Bennett (177) and Gregory (178) indicate that 
several investigators attribute the disease to hemolytic strains of Escherichia coli. The disease has been attributed to toxins eliminated into the intestines by the organisms. The isolation of E. coli from sick animals has not been convincing evidence, however, especially since adequately controlled transmission experiments generally have not been conducted which would eliminate an associated viral entity. For example, the successful transmission experiments of Gregory (179) resulting in typical edema disease, employed inocula from bowel contents which had not been handled to eliminate the presence of viruses. The use of conventional pigs as experimental animals also presented the possibility of activating latent virus by the experimental stresses imposed. Coliform bacteria vary in their pathogenicity. Saunders et al. (180) demonstrated that some strains lack pathogenicity even for hosts as susceptible as PFCD baby pigs. The most damaging evidence against the E. coli concept of edema disease is presented by Mansson (181). He consistently isolated hemolytic $E$. coli of the serotype associated with edema disease from both sick and healthy pigs within a herd over a nine-year period. Since edema disease was not observed among these pigs, Mansson concluded that other prerequisites must enter into this infection.

The erratic occurrence of edema disease within swine herds, with affliction of the best and fastest growing pigs has often been interpreted as death due to enterotoxins produced by E. coli. Any explanation involving an infectious viral entity can be as logical. A carrier state is effected with the edema agent by modification of the disease within immune animals. Virus is carried and shed almost continuously in an infected herd. Newborn pigs are protected during the early suckling period through colostral immunity as their dams have had previous or continuous exposure to the edema disease agent. Since the newborn pig of approximately $2.5 \mathrm{lbs}$ absorbs its protective lactoglobulins early and reaches about $25 \mathrm{lbs}$ before it produces appreciable amounts of protective gamma globulin of its own, the most rapidly growing pigs would have the least relative protection through passive immunity. Exposure to infections in their natural environment would more seriously effect the larger and apparently most healthy pigs. The small pigs would possess more antibody units per pound of body weight, react to virus subclinically, or manifest only mild clinical symptoms and recover. Passive immunity would be replaced by active immunity and the animals would have less difficulty thriving in an environment in which there was repeated exposure to edema disease.

Exudative epidermitis of swine - Exudative epidermitis is another disease of swine which had previously been classed as noninfectious and of unknown cause. A common farm term is "greasy pig disease" because of the brown, slimy exudate which covers the skin. The primary cause, first identified by Underdahl et al. (182), is a filterable virus. Pathogen-free colostrumdeprived pigs consistently develop mild vesicular lesions from filtrates of naturally infected tissues. The addition of some strains of streptococci or Proteus intensify the infections to produce lesions as severe as those seen in nat- 
ural field cases. Relationship of the bacteria to epidermitis is in need of further evaluation.

The previous classification of exudative epidermitis as noninfectious was based on the characteristics of the natural disease. Generally, only a few nursing pigs in a herd are afflicted. Littermates may remain perfectly normal. Since experimental epidermitis, through study with several thousand PFCD pigs over a 15-year period (85), has been found to be the most infectious disease among these animals, some explanation seems necessary. In herds where it has occurred, immunity developed by the sows is transmitted to the next generation through colostral milk. In large litters, some pigs are crowded away from the dam and fail to get enough colostral milk to protect them fully. These pigs develop severe lesions. Since their littermates remain normal, the disease has been considered by Wellman (183) to be noninfectious with a heritable or erroneous nutritional cause. The primary causative agent may persist in carrier animals within a population for several years. The virus remains as a source of infection for new pigs and stimulates some degree of immunity among the other animals.

Foot-and-mouth disease and rinderpest - Foot-and-mouth disease and rinderpest are two extremely important diseases of cattle but are not currently of economic importance in the United States. Since neither disease is endemic in our herds, study of these diseases is limited to laboratories outside the country. A United States Department of Agriculture laboratory has been established on Plum Island, off Long Island, New York, for this type of study. Research of both practical (184) and basic nature (185) is being conducted there to obtain information necessary to the control of foot-and-mouth disease. Liaison is maintained with Canadian officials for the use of special island laboratory facilities for challenge of United States cattle recovered from diseases with rinderpest-like symptoms. Thus far, suspects have had bovine virus diarrhea and were fully susceptible to virulent rinderpest virus. A continual vigilance must be maintained, however, as a safeguard against the establishment and spread of exotic cattle disease.

\section{Disease Control}

One of the obstacles to the control of viral infections of domestic animals has been the ideology that disease is inevitable. Animals, under this philosophy, must live with diseases and become adapted to them. "Control" is effected by modification of disease by changes in diet, changes in environment, and retention of breeding animals best able to survive and thrive under the conditions imposed. The "live with" philosophy includes the use of drugs such as antibiotics, sulfonamides, and arsenicals in animal feeds, and as medicants. Vaccines are also utilized for those diseases to which antibody can be developed in response to injection of antigens to supplement or better govern disease as it occurs in nature. Many of these vaccines are directed at the control of bacterial infections which would effect viral infections in a second- 
ary way. This would also seem to be the role played by the drugs fed as additives since they are not generally effective against the multitude of viruses which plague animal populations.

Developments in animal production in recent years have used an old, old concept of isolation to control animal disease. Lancisi, as interpreted by Fleming (186), in the early 1700's expressed his belief that the virus of foot-and-mouth disease gained access to the body by the air passages and stomach. His concept of control was by isolation inasmuch as cattle in monasteries escaped the contagion even when located in the center of the plaguehaunted districts. He attributed the absence of disease to "cattle having no communication whatever with those beyond the high walls enclosing their pastures."

It is recognized that the problems of controlling human diseases by isolation is incompatible with the process of living, and, as expressed by Dubos (187) relating to man, " Disease will remain an inescapable manifestation of his struggles." In some disagreement with Dubos, it is known that practical control of many virus diseases of animals can be accomplished through isolation. Man's animals may be freed of specific virus diseases then need not have direct communication with other groups, as does man in his social order. Should a breakdown in isolation occur; permitting the animals to become infected, the virus may again be eliminated and a new disease-free populations formed.

The key to the successful control of virus diseases of animals by isolation has been the ability to prevent the exposure of the newborn animal to troublesome viruses in its dam's environment. The fetus is delivered aseptically by surgery near term. It may then be raised in an isolated environment as a PFCD animal with gradual conversion to a specific pathogen-free status. Practical isolation procedures, both for repopulation and research purposes as described by Young \& Underdahl $(188,189)$, Young et al. (190), and Underdahl \& Young $(191,192)$, have been adapted by other laboratories. The extended use of these methods for the production of SPF pigs by others has been reviewed by Young (193).

In repopulation for practical livestock production, animals raised in laboratory isolation are eventually placed on farms from which other livestock have been removed. The new stock is reproduced by natural birth for succeeding generations but without contact with animals of the same species which have not had similar origin. This procedure has been successfully used in the development of a multi-thousand population of SPF pigs in a practical on-the-farm disease control program [See Caldwell (194); Caldwell et al. $(195,196,197)$; Underdahl et al. (198) ; Welch (199) ; and Young et al. (200, 201)], which has been especially useful in the elimination of atrophic rhinitis and virus pneumonia.

Similar programs have been established in other areas of the United States. Controlled studies on swine repopulation in Canada using SPF animals have been reported by Abelseth et al. (202), with promising results for 
the control of rhinitis and virus pneumonia. Studies in England by Betts et at. (203) are primarily directed toward control of the latter disease. National standards for minimal-disease pigs, equivalent to American SPF, have recently been established by the Pig Industry Development Authority (204).

The principles successfully applied to swine repopulation basically have potential usefulness for the eradication or control of many diseases of domestic animals. The primary problem would appear to be to justify effort and cost in relation to the value of the stock involved and the importance of eliminating a given disease or group of diseases. 


\section{Literature Cited}

1. Enders, J. F., A.I.B.S. Bull. Biosciences, 13, 30-32 (1963)

2. Rayniers, J. A., Ann. N.Y. Acad. Sci., 78, 3-16 (1959)

3. Luckey, T. D., Germfree Life and Gnotobiology, 419-22 (Academic Press, New York and London, 512 pp., 1963)

4. Gordon, H. A., Ann. N.Y. Acad. Sci., 78, 208-20 (1959)

5. Young, G. A., in Advan. Vet. Sci., in press (Brandly, C. A., and Jungherr, E. L., Eds. Academic Press, New York, 1964)

6. Meyer, R. C., Bohl, E. H., Henthorne,

R. D., Thorp, V. L., and Baldwin, D. E., Lab. Animal Care Suppl., 13, 655-64 (1963)

7. Teah, B. A., Bibliography of Germfree Research, 43 (Lobund Lab., Univ. of Notre Dame, Notre Dame, Indiana, 1964)

8. Olson, C., Am. J. Vet. Res., 16, 458-62 (1955)

9. Yager, R. H., J. Am. Vet. Med. Assoc., 141, 848-50 (1962)

10. Sweat, R. L. (Personal communication, 1963)

11. Grace, O. D., Underdahl, N. R., and Young, G. A., Am. J. Vet. Res., 20, $239-41$ (1959)

12. Kulangara, A. C., and Schechtman, A. M., Proc. Soc. Expt. Biol. Med., 112, $220-22$ (1963)

13. Payne, L. C., and Marsh, C. L., Federation Proc., 21, 909-12 (1962)

14. Mason, J. H., and Dalling, T., J. Pathol. Bacterial., 33, 783-93 (1930)

15. Payne, L. C., and Marsh, C. L., J. Nutr., 76, 151-58 (1962)

16. Segre, D., and Kaeberle, M. L., J. Immunol., 89, $782-89$ (1962)

17. Segre, D., and Kaeberle, M. L., Ibid., 89, 790-93 (1962)

18. Sterzl, J., Kostka, J., Ritia, I., and Mandel, L., Folia Microbiol. (Prague), 5, $29-45$ (1960)

19. Weiss, K. E., Onderstepoort J. Vet. Res. Med., 29, 3-9 (1962)

20. Aiken, J. M., and Blore, I. C. (Personal communication, 1963)

21. Fennestad, K. L., and Borg-Petersen, C., Nature, 180, 1210-11 (1957)

22. Hoerlein, A. B., J. Immunol., 78, 112-17 (1957)

23. Aiken, J. M., Immunologic Response of Newborn Colostrum-Deprived Pigs to Lapinized Hog Cholera Virus. (Master Sci. thesis, Univ. of Nebraska, Lincoln, 1963)

24. Coggins, L., Effect of Colostral Hog Cholera Antibody on Immunity to Hog Cholera (74) (Centennial Meeting Am. Vet. Med. Assoc., New York, August, 1963)

25. Dunne, H. W., J. Am. Vet. Med. Assoc., 138, 311-16 (1961)

26. Weide, K. D., Sanger, V. L., and Lagace, A., J. Am. Vet. Med. Assoc., 141, $464-69$ (1962)

27. Weide, K. D., and Sanger, V. L., J. Am. Vet. Med. Assoc., 141, 470-75 (1962)

28. Bekkum, J. G., Frenkel, S., and Nathans, I., Tijdschr. Diergeneesk., 88, 1936-44 (1963)

29. Livingston, C. W., and Hardy, W. T., Southwestern Vet., 11, 27-28 (1957)

30. Brown, R. D., J. Hyg., 56, 435-44 (1958)

31. Haelterman, E. O., Proc. World Vet. Congr., 17th, Hannover, 1, 615-24 (1963)

32. Blattner, R. J., and Heys, F. W., Progr. Med. Virol., 3, 311-62 (1961)

33. Rhodes, A. J., in Congenital Malformations, 106-16 (Fishbein, M., Ed., Lippincott, Philadelphia, 314 pp., 1962)

34. Rhodes, A. J., in Birth Defects, 171-80, (Fishbein, M., Ed., Lippincott, Philadelphia, Pa., 335 pp., 1963)

35. Roberts, S. J., J. Am. Vet. Med. Assoc., 140, 691-98 (1962)

36. Young, G. A., J. Am. Vet. Med. Assoc., 121, $394-96$ (1952)

37. Young, G. A., Proc. Am. Vet. Med. Assoc. 377-81 (92nd Ann. Meeting, Minneapolis, Minn., August, 1955) 
38. Young, G. A., Kitchell, R. L., Luedke, A. J., and Sautter, J. H., J. Am. Vet. Med. Assoc., 126, 165-71 (1955)

39. Stair, E. L., Keskintepe, H., and Young, G. A. (Unpublished data, 1963)

40. Burns, K. F., Proc. Soc. Exptl. Biol. Med., 75, 621-25 (1950)

41. Shimizu, T., Kawakami, Y., Fukuhara, S. and Matumoto, M., Japan. J. Exptl. Med., 24, 363-75 (1954)

42. Gordon, W. A. M., and Luke, D., Vet. Record (London), 67, 591-97 (1955)

43. Schultz, G., and DeLay, P. D., J. Am. Vet. Med. Assoc., 127, 224-26 (1955)

44. Findlay, G. M., Trans. Roy. Soc. Trop. Med. Hyg., 25, 229-65 (1931-32)

45. Weiss, K. E., Haig, D. A., and Alexander, R. A., Onderstepoort J. Vet. Res., 27, 183-95 (1956)

46. Belonje, C. W. A., J. So. Africa Vet. Med. Assoc., 29, 1-12 (1958)

47. le Roux, J. M. W., Onderstepoort J. Vet Res., 28, 237-43 (1959)

48. Parker, H. D., and Younger, R. L., Am. J. Vet. Res., 23, 981-84 (1962)

49. Kokernot, R. H., De Meillon, B., Patterson, H. E., Haymann, C. S., and Smithburn, K. S., So. Africa J. Med. Sci., 22, 145-58 (1957)

50. Mirand, E. A., and Grace, J. T., Virology, 16, 344-47 (1962)

5 1. Pierce, K. R., Moore, R. W., Carroll, L. H., and Bridges, C. H., Am. J. Vet. Res., 24, 1176-87 (1963)

52. Kennedy, P. C., Olander, H. J., and Howarth, J. A., Cornell Vet., 50, 417-29 (1960)

53. Storz, J., McKercher, D. G., Howarth, J. A., and Straut, O., J. Am. Vet. Med. Assoc., 137, 509-14 (1960)

54. McKercher, D. G., and Wada, E. M., J. Am. Vet. Med. Assoc., 144, 136-42 (1964)

55. Gregg, N. McA., Trans. Ophthalmol. Soc. (Australia), 3, 35-46 (1942)

56. Heuser, C. H., and Streeter, G. L., Contrib. Embryol., 20, 1-29 (1929)

57. Stair, E. L., Jr., Bifid Hysterectomy for Study of Viral Induced Congenital Malformations (Master Sci. thesis, Univ. of Nebraska, Lincoln, 1963)

58. Shope, R. E., J. Exptl. Med., 54, 349-59 (1931)

59. Lewis, P. A., and Shope, R. E., J. Exptl. Med., 54, 361-71 (1931)

60. Shope, R E., J. Exptl. Med., 74, 41-47 (1941)

61. Shope, R E., Ibid., 49-68 (1941)

62. Shope, R. E., Ibid., 77, 111-26 (1943)

63. Shope, R K, Ibid., 127-38 (1943)

64. Sen, H. G., Kelley, G. W., Underdahl, N. R., and Young, G. A., J. Exptl. Med., 113, 51720 (1961)

65. Kammer, H., and Hanson, R. P., J. Infect. Diseases, 110, 99-102 (1962)

66. Peterson, W. D., Davenport, F. M., and Francis, T., J. Exptl. Med., 1 14, 1023-33 (1961)

67. Beard, J. W., Cancer Res., 16, 279-91 (1956)

68. Underdahl, N. R, and Kelley, G. W., J. Am. Vet. Med. Assoc., 130, 173-76 (1957).

69. Underdahl, N. R, J. Am. Vet. Med. Assoc., 133, 380-83 (1958)

69a. Nayak, D. P., Kelley, G. W., and Underdahl, N. R., Cornell Vet. (In press, 1964)

70. Young, G. A., Underdahl, N. R, and Kelley, G. W., Proc. Soc. Exptl. Biol. Med., 106, $592-$ $94(1961)$

71. Young, G. A., and Underdahl, N. R., Am. J. Vet. Res., 16, 545-52 (1955)

72. Kelley, G. W., Olsen, L. S., and Howe, E. C., Nebraska Expt. Sta. Circ. 1902, 1-10 (1958)

73. Kelley, G. W., and Sen, H. G., Nebraska J. Parasitol., 45, 41 (1960)

74. Young, G. A., in Diseases of Swine, 127-35 (Dunne, H. W., Ed., Iowa State Univ. Press, Ames, Iowa, 897 pp., 1964) 
75. Young, G. A., and Underdahl, N. R., J. Am. Vet. Med. Assoc., 137, 186-89 (1960)

76. Betts, A. O., Vet. Record (London), 64, 283-88 (1952)

77. Lamont, H. G., Vet. Record (London), 50, 1377-1400 (1938)

78. Bakos, K., and Dinter, Z., Proc. World Vet. Congr. 17th, Hannover, 1, 549-54 (1963)

79. Betts, A. O., and Whittlestone, P., Res. Vet. Sci. (Oxford), 4, 471-79 (1963)

80. Goodwin, R. F. W., and Whittlestone, P., Brit. J. Exptl. Pathol., 44, $291-99$ (1963)

81. Urman, H. K., Underdahl, N. R., and Young, G. A., Am. J. Vet. Res., 19, 913-17 (1958)

82. Plonait, H. (Personal communication, 1963)

83. Goodwin, R. F. W., and Whittlestone, P., Brit. J. Comp. Pathol., 72, 389-410 (1962)

84. Bornfors, S., and Lannek, N., Nord. Veterinarmed., 10, 426-30 (1958)

85. Young, G. A. (Personal experiences through 1963)

86. Goret, P., Fontaine, M., Brion, A., Pilet, C., Girard, M., and Legrand, P., Bull. Acad. Vet. (France), 33, 303-4 (1960)

87. Hupka, E., and Hutten, H., Deut. Tieraerztl. Wochschr., 63, 444-47 (1956)

88. Switzer, W. P., J. Am. Vet. Med. Assoc., 127, 340-48 (1955)

89. Switzer, W. P., Am. J. Vet. Res., 17, 478-84 (1956)

90. Switzer, W. P., Ibid., 21, 967-70 (1960)

91. Switzer, W. P., Roberts, E. D., and L'Ecuyer, C., Am. J. Vet. Res., 22, 67-71 (1961)

92. Switzer, W. P., Vet. Med., 58, 571-74 (1963)

93. Done, F. T., Vet. Record (London), 67, 525-28 (1955)

94. Mitchell, D., and Corner, A. H., J. Comp. Med. Vet. Sci., 22, 199-202 (1958)

95. Cohrs, P., Deut. Tieraerztl. Wochschr., 66, 605-7 (1959)

96. Duncan; J. R., Ross, R. F., and Switzer, W. P., J. Am. Vet. Med. Assoc., 144, $33-37$ (1964)

97. Madin, S. H., York, C. J., and McKercher, D. G., Science, 124, 72 1-22 (1956)

98. McKercher, D. G., Moulton, J. E., Madin, S. H., and Kendrick, J. W., Am. J. Vet. Res., 18, 246-56 (1957)

99. Brown, R. G., and Cabasso, V. J., Vet. Med., 52, 321-26 (1957)

100. Gillespie, J. H., McEntee, K., Kendrick, J. W., and Wagner, W. C., Cornell Vet., 49, 288-95 (1959)

101. Cheatham, W. J., and Crandell, R. A., Proc. Soc. Exptl. Biol. Med., 96, 536-38 (1957)

102. Crandell, R. A., Cheatham, W. J., and Maurer, F. D., Am. J. Vet. Res., 20, 505-9 (1959)

103. Gillespie, J. H., Lee, K. M., and Baker, J. A., Am. J. Vet. Res., 18, 530-35 (1957)

104. Cabasso, V. J., Brown, R. G., and Cox, H. R., Proc. Soc. Exptl. Biol. Med., 95, 471-76 (1957)

105. Schwarz, A. J. F., York, C. J., Zirbel, L. W., and Estela, L. A., Proc. Soc. Exptl. Biol. Med., 96, 453-58 (1957)

106. Schwarz, A. J. F., Zirbel, L. W., Estela, L. A., and York, C. J., Ibid., 97, 680-83 (1958)

107. Reisinger, R. C., Heddleston, K. L., and Manthei, C. A., J. Am. Vet. Med. Assoc., 135, 147-52 (1959)

108. Hoerlein, A. B., Mansfield, M. E., Abinanti, F. R., and Huebner, R. J., J. Am. Vet. Med. Assoc., 135, 153-60 (1959)

109. Abinanti, F. R., Hoerlein, A. B., Watson, R. L., and Huebner, R. J., J. Immunol., 86, 505-11 (1961)

110. Kramer; L. L., Sweat, R. L., and Young, G. A., J. Am. Vet. Med. Assoc., 142, 375-78 (1963)

111. Dawson, P. S., Res. Vet. Sci. (Oxford), 5, 81-88 (1963)

112. Hamdy, A. H., Trapp, A. L., and Gale, C., Am. J. Vet. Res., 25, 128-33 (1964) 
113. Sykes, J. A., Dmochowski, L., Gray, C. E., and Russell, W. O., Proc. Soc. Exptl. Biol. Med., 111, 51-57 (1962)

114. Underdahl, N. R., Grace, O. D., and Hoerlein, A. B., Proc. Soc. Exptl. Biol. Med., 94, 795-97 (1957)

115. Hancock, B. B., Bohl, E. H., and Birkeland, J. M., Am. J. Vet. Res., 20, 127-32 (1959)

116. Singh, K. V., Cornell Vet., 52, $71-77$ (1962)

117. Kasza, L., Graf, G., and Kovach, J. L., Am. J. Vet. Res., 23, 1150-56 (1962)

118. Huck, R. A., Cartwright, S. F., Yamanouchi, K., Bankowski, R. A., and Howarth, J. A., Am. J. Vet. Res., 24, 1207- 11 (1963)

119. Chaproniere, D. M., Done, J. T., and Andrewes, C. H., Brit. J. Exptl. Pathol., 39, 74-77 (1958)

120. Darbyshire, J. H., and Dawson, P. S., Res. Vet. Sci. (Oxford), 4, 48-55 (1963)

121. Izawa, H., Bankowski, R. A., and Howarth, J. A., Am. J. Vet. Res., 23, 1131-41 (1962)

122. Betts, A. O., Res. Vet. Sci. (Oxford), 1, 57-64 (1960)

123. Betts, A. O., Ibid., 1, 160-71 (1960)

124. Greig, A. S., Mitchell, D., Corner, A. H., Bannister, G. L., Meads, E. B., and Julian, R. J., Can. J. Comp. Med. Vet. Sci., 26, 49-56 (1962)

125. Greig, A. S., Bannister, G. L., Mitchell, D., and Corner, A. H., Can. J. Comp. Med. Vet. Sci., 25, 142-50 (1961)

126. Kelly, D. F., Res. Vet. Sci. (Oxford), 5, 56-70 (1963)

127. Doyle, L. P., in Diseases of Swine, 107-10 (Dunne, H. W., Ed., Iowa State Univ. Press, Ames, Iowa, 716 pp., 1958)

128. Young, G. A., Hinz, R. W., and Underdahl, N. R., Am. J. Vet. Res., 16, 529-35 (1955)

129. Young, G. A., Underdahl, N. R., and Hinz, R. W., Cornell Vet., 43, 561-66 (1953)

130. Lee, K. M., Ann. N.Y. Acad. Sci., 66, 191-95 (1956)

131. Eto, M., Jchihara, T., Tsunoda, T., and Watanabe, S., J. Japan Vet. Med. Assoc., 15, 16$20(1962)$

132. Roe, C. K., and Alexander, T. J. L., Can. J. Comp. Med. Vet. Sci., 22, 305-7 (1958)

133. Goodwin, R. F. W., and Jennings, A. R., Vet. Record (London), 70, 271-72 (1958)

134. Goodwin, R. F. W., and Jennings, A. R., J. Comp. Pathol. Therap., 69, 313-26 (1959)

135. Beran, G. W., Werder, A. A., and Wenner, H. A., Am. J. Vet. Res., 19, 545-53 (1958).

136. Beran, G. W., Wenner, H. A, Werder, A. A., and Underdahl, N. R., Am. J. Vet. Res., 21, 723-33 (1960)

137. Coggins, L., Am. J. Vet. Res., 25, 103-7 (1964)

138. Baker, J. A., York, C. J., Gillespie, J. H., and Mitchell, G. B., Am. J. Vet. Res., 15, 52531 (1954)

139. Lee, K. M., and Gillespie, J. H., Am. J. Vet. Res., 18, 952-53 (1957)

140. Carlson, R. G., Pritchard, W. R., and Doyle, L. P., Am. J. Vet. Res., 18, 560-68 (1957)

141. Noice, F., and Schipper, I. A., Proc. Soc. Exptl. Biol. Med., 100, $84-86$ (1959)

142. Baker, J. A., Gillespie, J. H., Sheffy, B. E., and Marshall, V., Cornell Vet., 48, 207-13 (1958)

143. Dorset, M., Bolton, B. M., and McBryde, C. N., U.S. Dept. Agr., Bur. Animal Ind., 21st Ann. Rept. (1904).

144. Hanson, R. P., J. Am. Vet. Med. Assoc., 131, 211-18 (1957)

145. Fleming, G., Animal Plagues: Their History, Nature, and Prevention (A.D. 1800-1844), 80-81 (Bailliere, Tindall, and Cox, London, 539 pp., 1882)

146. Mainwaring, G. T., and Sorensen, D. K., Symposium on Hog Cholera (Univ. of Minnesota and U.S. Dept. Agr., St. Paul, Minnesota, October, 1961) 
147. Dorset, M., McBryde, C. N., and Niles, W. B., U.S. Dept. Agr., Bur. Animal Ind., Bull. No. 102 (1908)

148. Koprowski, H., James, T. R., and Cox, H. R., Proc. Soc. Exptl. Biol. Med., 63, 17 8-82 (1946)

149. Baker, J. A., Proc. Soc. Exptl. Biol. Med., 63, 183-87 (1946)

150. Dunne, H. C., in Diseases of Swine, 132-34 (Dunne, H. C., Ed., Iowa State Univ. Press, Ames, Iowa, 716 pp., 1958)

151. Taylor, R. L., Haver-Lockhart Messenger, 39, 5-6 (1959)

152. Newberne, J. W., Johnston, R. V., Robinson, V. B., York, C. J., and Sanders, E. F., Vet. Med., 54, 41-47 (1959)

153. Beckenhauer, W. H., Brown, A. L., Lidolph, A. A., and Norden, C. J., Vet. Med., 56, 108-12 (1961)

154. Atkinson, G. F., Baker, J. A., Campbell, C., Coggins, L., Nelson, D., Robson, D., Sheffy, B. E., and Sippel, W., Proc. U.S. Livestock Sanitary Assoc. (Washington), 326-38 (1962)

155. Sheffy, B. E., Coggins, L., and Baker, J. A., Proc. Soc. Exptl. Biol. Med., 109, 349-52 (1962)

156. Gutekunst, D. E., and Malmquist, W. A., Can. J. Comp. Med. Vet. Sci., 27, 121-23 (1963)

157. Mengeling, W. L., Gutekunst, D. E., Fernelius, A. L., and Pirtle, E. C., Can. J. Comp. Med. Vet. Sci., 27, 162-64 (1963)

158. Coggins, L., and Seo, S., Proc. Soc. Exptl. Biol. Med., 114, 778-80 (1963)

159. Dunne, H. W., Vet. Med., 53, 222-39 (1963)

160. Gustafson, D. P., and Pomerat, C. M., Am. J. Vet. Res., 18, 473-80 (1957)

161. Lee, R. C. T., Cornell Vet., 52, 39-51 (1962)

162. Urman, H. K., Underdahl, N. R., Aiken, J. M., Stair, E. L., and Young, G. A., J. Am. Vet. Med. Assoc., 141, 571-81 (1962)

163. Millian, S. J., and Engelhard, W. E., Am. J. Vet. Res., 22, 396-400 (1961)

164. Segre, D., Am. J. Vet. Res., 23, 748-51 (1962)

165. McClurkin, A. W., Can. J. Comp. Med. Vet. Sci., 27, 275-79 (1963)

166. Pirtle, E. C. Can. J. Comp. Med. Vet. Sci., 27, 241-48 (1963)

167. Taylor, R. L., Vet. Med., 56, 229-32 (1961)

168. McDevitt, H. O., Peters, J. H., Pollard, L. W., Harter, J. G., and Coons, A. H., J. Immunol., 90, 634-42 (1963)

169. Stair, E. L., Rhodes, M. G., Aiken, J. M., Underdahl, N. R., and Young, G. A., Proc. Soc. Exptl. Biol. Med., 113, 656-60 (1963)

170. Aiken, J. M., Hoopes, K. H., Stair, E. L., and Rhodes, M. B., J. Am. Vet. Med. Assoc., 144 , in press (1964)

171. Mengeling, W. L., Pirtle, E. C., and Torrey, J. P., Can. J. Comp. Med. Vet. Sci., 27, 24953 (1963)

172. Malmquist, W. A., and Hay, D., Am. J. Vet. Res., 21, 104-8 (1960)

173. De Tray, D. K, Am. J. Vet. Res., 18, 811-16 (1957)

174. Underdahl, N. R., Blore, I. C., and Young, G. A., J. Am. Vet. Med. Assoc., 134, 367-70 (1959)

175. Underdahl, N. R., Blore, I. C., and Young, G. A., Ibid., 135, 615-17 (1959)

176. Underdahl, N. R., Stair, E. L., and Young, G. A., J. Am. Vet. Med. Assoc., 142, 27-30 (1963) 